\title{
Impact of the Use of Ethanolic Extract of Propolis, Flavonoid and Non-Flavonoid Propolis for Direct Pulp Capping in Collagen Type I Density
}

\author{
Ardo Sabir', Latief Mooduto', Cahyono Kaelan ${ }^{3}$, Sherly Horax ${ }^{4}$ \\ ${ }^{1}$ Department of Conservative Dentistry, Faculty of Dentistry, Hasanuddin University, Makassar 90245, Indonesia \\ 2Department of Conservative Dentistry, Faculty of Dentistry, Airlangga University, Surabaya 60132, Indonesia \\ ${ }^{3}$ Department of Pathological Anatomy, Faculty of Medicine, Hasanuddin University, Makassar 90245, Indonesia \\ ${ }^{4}$ Department of Pediatric Dentistry, Faculty of Dentistry, Hasanuddin University, Makassar 90245, Indonesia
}

\begin{abstract}
Aim: To analysis collagen type I density on inflamed rat dental pulp after capping with propolis. Methods: Flavonoid and non-flavonoid substances were purified from propolis. Eighty male rats were divided into five groups, each group consisting of 16 rats. As a negative control (group I), rats were not conducted any treatment. A class I cavity was prepared on the occlusal surface of right maxillary first molar. Dental pulp was exposed and allowed in oral environment for 60 minutes, then dental pulp capping with ethanolic extract of propolis (group II), flavonoid propolis (group III), non-flavonoid propolis (group IV), or calcium hydroxide as positive control (group V). Rats were sacrificed at 6 hours, 2, 4 or 7 days, biopsy samples were obtained, stained and viewed by light microscope. Data was statistically analysis using Friedman and Kruskal-Wallis tests. Results: Except in group I, collagen type I density was increased in group II, III, and V with the longer of observation time periods. However, in group IV, collagen type I density increased only on day 7 . No statistically significant differences of collagen type I density among the groups for each time period were found. Conclusions: Propolis and flavonoid propolis may increase collagen density on inflamed rat dental pulp.
\end{abstract}

Keywords: Propolis. Collagen type I. Inflammation. Dental pulp. Rat.

Received for publication: December 12, 2016 Accepted: July 23, 2017

Correspondence to: Dr. Ardo Sabir, DDS, M.Kes Department of Conservative Dentistry

Faculty of Dentistry

Hasanuddin University, Makassar 90245, Indonesia Phone : +62-81524301953, +62-411-586012; Fax : +62-411-584641 E.mail : ardo.sabir@yahoo.com

\section{Introduction}

Propolis, or bee glue is a natural wax-like resinous substance collected by bees from buds and exudates of the plants ${ }^{1}$. Honey bees used propolis as antibiotic, seal hole or cracks of its combs, and also protect it from insects ${ }^{2}$. Propolis has been used since long time ago as traditional medicine due to its several biological properties, such as antibacterial $^{3}$, anti-inflammatory ${ }^{4}$, and immunomodulatory ${ }^{5}$. Among of its constituents, both flavonoid and non-flavonoid substances of propolis also showed anti-bacterial and anti-inflammatory activities. The chemical composition of propolis is very complex, depends on the collecting location, time, and plant source ${ }^{6}$. Commonly, the composition of propolis primarily consists of resinous (50\%), wax (30\%), essential and aromatics oils $(10 \%)$, bee pollen $(5 \%)$, and other substances $(5 \%)^{7}$. 
In recent years, a new trend of using complementary and alternative medicines including apitherapy has increased worldwide. Using propolis in conservative dentistry and endodontic treatment to treat tooth and pulp diseases is a popular practice such as cariostatic agent in suppressing cariogenic bacteria $^{8}$, desensitizing agent to treat hypersensitivity dentin ${ }^{9}$, intracanal irrigant ${ }^{10}$, cavity disinfecting agent in atraumatic restorative treatment ${ }^{11}$, medicament during root canal treatment ${ }^{12}$, and also as direct pulp capping agent ${ }^{13}$.

Dental pulp is a loose connective tissue uniquely situated within the rigid encasement of mineralized dentin. However, dental pulp may become exposed due to caries, accidental mechanical during cavity preparation, tooth fracture or attrition ${ }^{14}$. Collagen is a major organic component of macromolecular structures in the dental pulp, designated as collagen fibers. Collagen type I play pivotal role during wound healing process, especially in hemostatis, inflammatory response, cell growth, differentation and migration ${ }^{15,16}$. Previous studies have demonstrated that propolis is toxic to dental pulp fibroblasts at $2 \mathrm{mg}$ or above ${ }^{17}$ and not reduced the viability of dental pulp fibroblasts at $1 \mathrm{mg} / \mathrm{mL}^{18}$.

One of honeybee species that breeding by many beekeepers in South Sulawesi province, Indonesia is Trigona sp. This honeybee species is stingless and can produce a lot of propolis. Therefore, the aim of the present study was to evaluate the impact of the use of ethanolic extract of propolis, flavonoid propolis and non-flavonoid propolis for direct pulp capping in collagen type I density.

\section{Material and Methods}

The experimental protocol was approved by the ethical committee of Faculty of Medicine, Hasanuddin University number 0032/H04.8.4.5.31/PP36-KOMETIK/2015.

\section{Animals}

Eighty Sprague Dawley rats (male, 8-16 weeks old, weight 200-300 g), obtained from the Animal Research Development Center, Gadjah Mada University, Yogyakarta Indonesia with standard food and water ad libitum throughout the experiment. The room was maintain on a $12 \mathrm{~h}$ light-dark schedule at a temperature of $26 \pm 2{ }^{\circ} \mathrm{C}$ and a relative humidity of $60-70 \%$.

\section{Propolis}

Raw propolis was purchased from Honey Bee Development Center, Hasanuddin University, Makassar which collected from honeycombs in Luwu regency, South Sulawesi Province, Indonesia in the early monsoon season.

\section{Extraction of propolis}

Dried propolis $(250 \mathrm{~g})$ was sliced and squashed with a mortar and pestle, and the extract was cultured for five days in the dark at $45^{\circ} \mathrm{C}$ with continous shaking (100 rpm) in a flask containing ethyl alcohol $(95 \%)$ at a ratio of 1:5. It was then filtered through Whatman paper, and the crude extract of propolis was dried at $60^{\circ} \mathrm{C}$ using a vacuum rotary evaporator to get ethanolic extract of propolis. The residue was separated using toluene solution to yield flavonoid and non-flavonoid fraction, which were then subjected to thin layer chromatography using silica gel GF254 precoated plates with n-butanol: acetic acid: water $(3: 1: 1 \mathrm{v} / \mathrm{v})$ as mobile phase. Examination under ultraviolet light at $\lambda 253$ and $\lambda 366 \mathrm{~nm}$ and treatment with ammonia showed that the flavonoids group from propolis contains flavones, flavonoles, flavanols, and chalcones ${ }^{19}$.

\section{Experimental groups and treatment}

Rats were divided into five groups randomly, each consisting of 16 animals. Group I as a negative control was not conducted any treatment. In group II, III, IV and V, rats were anesthetized intramuscularly with ketamine (Ketalar ${ }^{\circledR}$, Warner Lambert, Ireland) (65 mg kg-1 body weight) and xylazine- $\mathrm{HCl}(\mathrm{Xyla} \AA$, Interchemie, Netherlands) (7 mg kg-1 body weight), and then Class I (Black's Classification) cavities were prepared on the occlusal surface of right maxillary first molar using a low-speed tapered round diamond bur (Intensiv ${ }^{\circledR}$, Switzerland) $(0.84 \mathrm{~mm}$ in diameter). The dental pulp was then exposed at the cavity floor using a dental explorer (Martin ${ }^{\circledR}$, Germany) $(0.35 \mathrm{~mm}$ in tip diameter) and allowed in the oral environment for 60 minutes, after that, dental pulp was immediately capping with ethanolic extract of propolis (EEP) (group II) $(0.5 \mathrm{mg}$ ), extract of flavonoid propolis (group III) $(0.5 \mathrm{mg}$ ), extract of non-flavonoid propolis (group IV) $(0.5 \mathrm{mg})$, or calcium hydroxide $\left(\mathrm{Ca}(\mathrm{OH})_{2}\right)\left(\mathrm{Hydcal}{ }^{\circledR}\right.$, Technew, Rio de Janeiro, Brazil) as positive control (group V) $(0.5 \mathrm{mg})$, respectively. Each cavity was then air-dried and filled with glass ionomer cement (HS Posterior Extra ${ }^{\circledR}$, GC, Tokyo, Japan) as permanent filling.

\section{Histological examination}

Four rats were sacrificed at 6 hours, 2 days, 4 days and 7 days respectively. The teeth and the surrounding bone were resected, fixed in Bouin's fixative solution for 24 hours, decalcified with acetic acid/ formal saline for 7 days, embedded in paraffin wax blocks and sliced into $6 \mu \mathrm{m}$-thick sections serially at bucco-palatal direction. The slides were stained with Mallory and examined under a light microscope (Leica®, Olympus BX41-U-CA, Tokyo, Japan) with 400x magnification. The scoring of collagen type I density on rat dental pulp was blindly evaluated by two separate independent pathologists. The density of collagen type I was scored according to the absent or presence of collagen type I, using a 0 to 2 score system : score 0 - no collagen type I was detected; score 1 - thin collagen type I was detected; and score 2 - thick collagen type I was detected. If there was any disagreement between the evaluators, the sample under discussion was jointly analyzed until a consensus was reached.

\section{Statistical analysis}

Statistical anaylsis was performed by using the SPSS-PC package for Windows (version 8.0, SPSS Inc, Chicago, USA). The Friedman test was used to analysis the significant difference of collagen type I density between observation time periods for each group. Meanwhile, for analysis the significant difference between the groups for each observation time period were evaluated by Kruskal-Wallis test. A value of $\mathrm{p}<0.05$ was considered statistically significant. 


\section{Results}

Histogram of collagen type I density on rats dental pulp tissue of all groups after 6 hours, 2 days, 4 days and 7 days of application can be seen at Figure 1. It was showed that collagen type I density was increased at group II, III, and V along with the increase of the observation time periods. Meanwhile, at group IV collagen type I density slight increased only on day 7. However, the result of Friedman and Kruskal-Wallis tests showed no significant difference $(p>0.05)$ of the collagen type I density among 4 time periods of each group (Table 1) and among 5 groups of each time period (Table 2). No necrotic pulp tissues were found in all animals of treatment groups throughout the study.

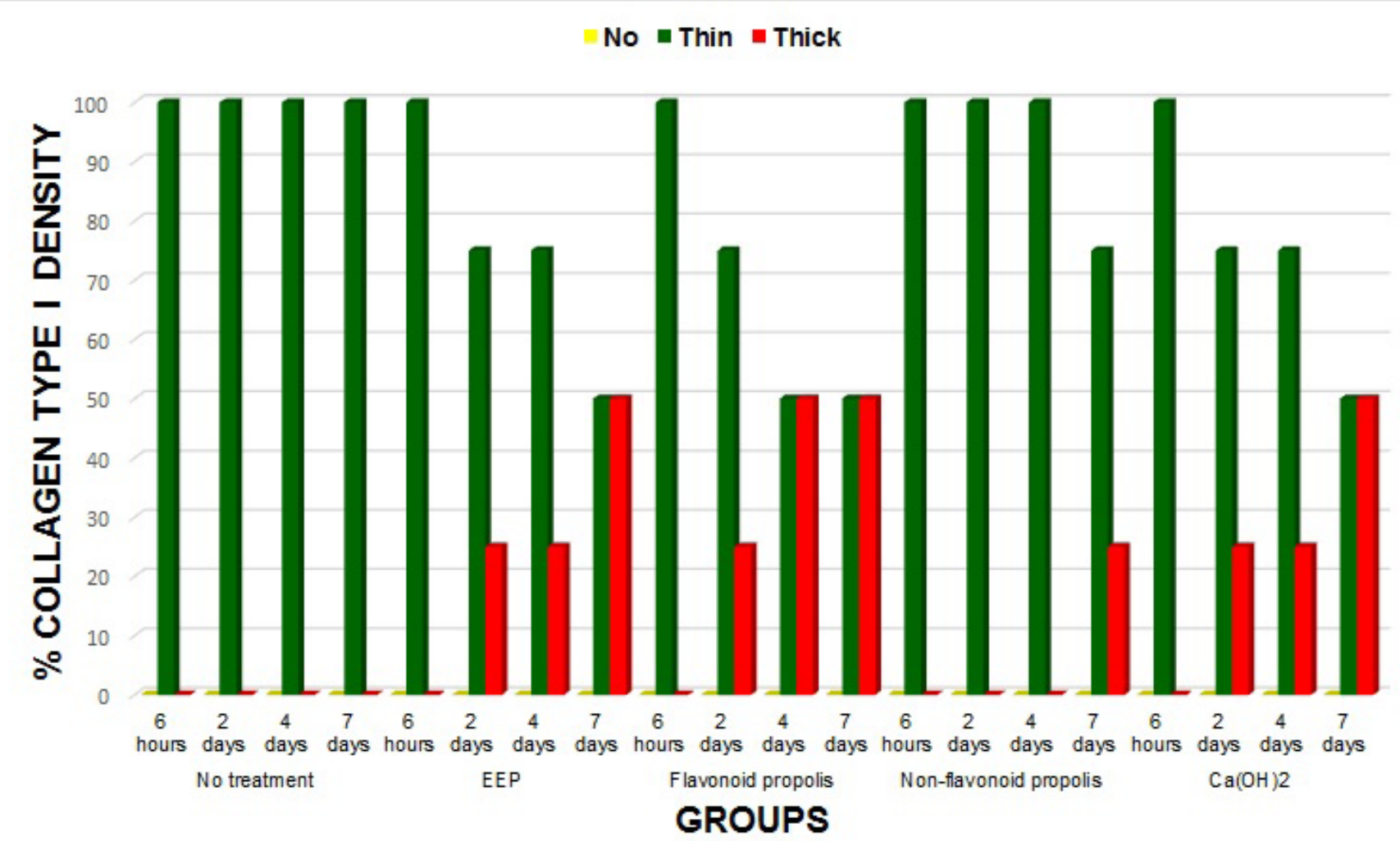

Fig. 1 - Histogram of percentage of collagen type I density on rats dental pulp tissue of all groups after 6 hours, 2 days, 4 days and 7 days of materials test application.

Table 1 - The difference of collagen type I density among time periods for each group.

\begin{tabular}{lccccc}
\hline \multirow{2}{*}{ Groups } & \multicolumn{3}{c}{ Mean Rank } & \multirow{2}{*}{ Freidman test } \\
\cline { 2 - 5 } & $\mathbf{6}$ hours & $\mathbf{2}$ days & $\mathbf{4}$ days & $\mathbf{7}$ days & 0.00 \\
No treatment & 2.50 & 2.50 & 2.50 & 2.50 & 1.00 \\
EEP & 2.00 & 2.50 & 2.50 & 3.00 & 0.494 \\
Flavonoid & 1.88 & 2.38 & 2.800 & 0.468 \\
Non-Flavonoid & 2.38 & 2.38 & 2.38 & 2.88 & 2.538 \\
$\mathrm{Ca}(\mathrm{OH})_{2}$ & 2.00 & 2.50 & 2.50 & 3.00 & 3.000 \\
\hline
\end{tabular}

Note: *Significant at $\mathrm{p}<0.05$

Table 2 - The difference of collagen type I density among groups for each time period.

\begin{tabular}{|c|c|c|c|c|c|c|c|}
\hline \multirow{2}{*}{ Time Periods } & \multicolumn{5}{|c|}{ Mean Rank } & \multirow{2}{*}{ Kruskal Wallis test } & \multirow{2}{*}{$p$} \\
\hline & No treatment & EEP & Flavonoid & Non-Flavonoid & $\mathrm{Ca}(\mathrm{OH})_{2}$ & & \\
\hline 6 hours & 10.50 & 10.50 & 10.50 & 10,50 & 10.50 & 0.000 & 1.000 \\
\hline 2 days & 9.00 & 11.50 & 11.50 & 9.00 & 11.50 & 2.235 & 0.693 \\
\hline 4 days & 8.50 & 11.00 & 13.50 & 8.50 & 11.00 & 4.156 & 0.385 \\
\hline 7 days & 7.00 & 12.00 & 12.00 & 9.50 & 12.00 & 3.341 & 0.503 \\
\hline
\end{tabular}

There was no statistically significant difference among the groups in each period $(p>0.05)$. 
The photomicrograph of collagen type I density evaluation is presented here in only by the section from all groups at 6 hours and 7 days (Figure 2).
6 hours
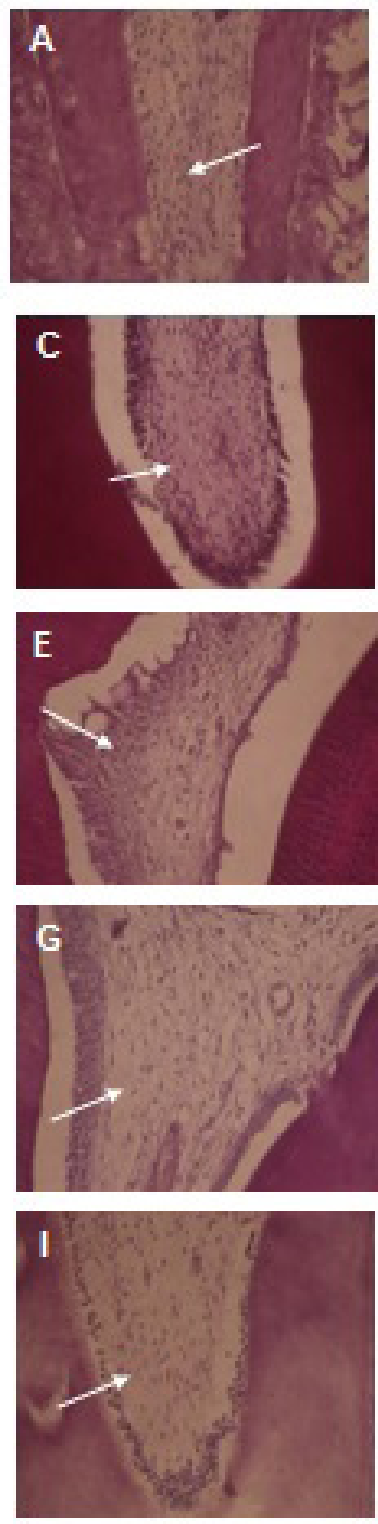

7 days
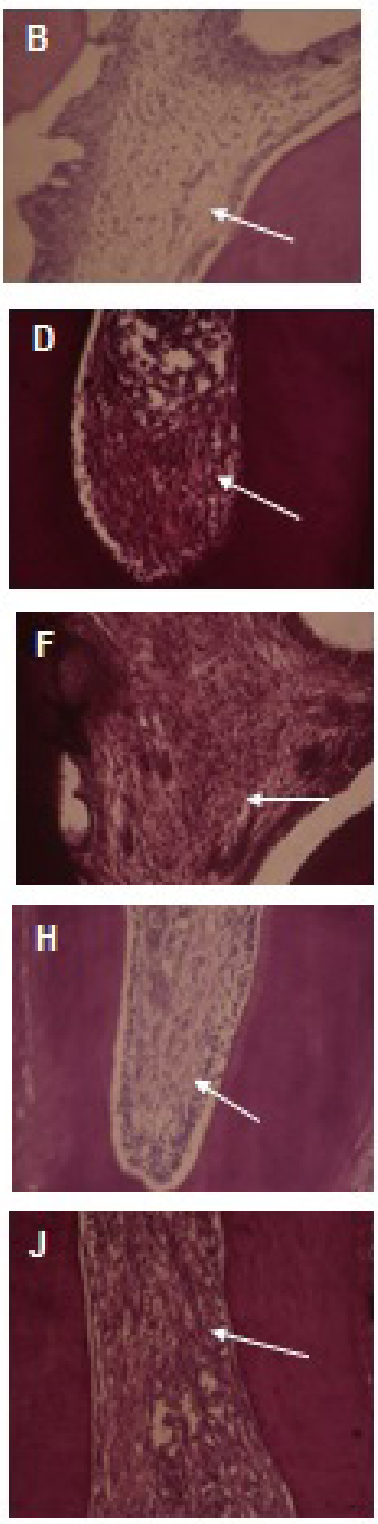

Fig. 2 - Collagen type I density on rats dental pulp tissue after materials test application for 6 hours and 7 days in groups I (A-B), II (C-D), III (E-F), IV (G-H) and V (I-J) with no treatment (negative control), ethanolic extract of propolis (EEP), extract of flavonoid-propolis, extract of non-flavonoid propolis and calcium hydroxide $\left(\mathrm{Ca}(\mathrm{OH})_{2}\right)$ (positive control), respectively. White arrows show collagen type I. Mallory stain, original magnification $400 \mathrm{x}$.

\section{Discussion}

Wound healing represents an interactive process which requires highly organized activity of many cells, synthesizing cytokines, growth factors, chemical mediators, extracellular matrix and collagen ${ }^{16}$. Healing mechanisms are a dynamic and continuous process that occurs when no inflammation is present. Proliferation and angiogenesis process will followed with connective tissue regeneration by collagen as results fibroblast cell synthesis ${ }^{20}$.

The present study showed that except in negative control group (without treatment), all treatment groups showed collagen type I in different density and tends to increased with the longer of observation time periods. However in group IV (nonflavonoid propolis), collagen type I density increased only on day 7. (Figure 1). The present results are not surprising, since propolis is known to have antibacterial, anti-inflammatory, antioxidant and immunomodulatory properties that permits cells regeneration and the healing process in dental pulp with collagen formation ${ }^{21,22}$. Previously study by Bretz et al. ${ }^{23}$ (1998) reported that propolis was effective to maintain the presence of fibroblast cells, low inflammatory and microbial cell population as well as in stimulating the formation of reparative dentin. These effects are mediated by the presence some of propolis constituents -such as active flavonoids, caffeic acid phenethyl ester, terpenoid, steroid, vitamin and minerals- that have a significant role in healing process $^{24}$.

The results of present study also showed that the collagen type I density was increased on inflamed rat dental pulp after capping with flavonid propolis. Study by Kandhare et al. ${ }^{25}$ (2014) in ulcer rat found that naringin (flavanone glycoside) was significant upregulation of mRNA expression of growth factor and collagen type I whereas mRNA expression of pro-inflammatory mediators was down-regulated. Further results suggest that angiogenesis was improved via naringin-mediated inhibition of oxidative stress, down-regulation of inflammatory mediator expression and up-regulation of growth factor expression, leading to improved wound healing of ulcer. Moreover, when inflammation was occurs, damage of blood vessels increases capillary permeability. Flavonoid substances have a significant role in maintaining permeability and increasing resistance of capillary blood vessels ${ }^{26}$. It will also increase biosynthesis mucopolysaccharide acid process of ground substances that finally caused both the number of new capillary blood vessel and collagen density were increased ${ }^{27}$. Our previous study in rats showed that flavonoid propolis could delay inflammation process and stimulated reparative dentin in direct pulp capping treatment ${ }^{28}$. In contrast, collagen type I density on inflamed rat dental pulp increased only on day 7 after capping with non-flavonoid propolis. (Figure 1). This result may due to that the antibacterial and anti-inflammatory properties of non-flavonoid substances weaker than other material test. Havsteen ${ }^{26}$ (2002) stated that flavonoids are considered as the most biologically active substance in propolis. Our previous study found that antibacterial activity of non-flavonoid propolis weaker than flavonoid propolis against Streptococcus mutans ${ }^{29}$.

Calcium hydroxide was used in this study as material of positive control group because until now it was known as the most promising capping agent for direct pulp capping treatment to preserve tooth vitality in an exposed pulp cavity. Nelson-Filho et al. ${ }^{30}$ (1999) reported that $\mathrm{Ca}(\mathrm{OH})_{2}$ initially induce the formation of a necrotic zone when contact with dental pulp tissue due to its high $\mathrm{pH}$ (11-12). Following infiltration of inflammatory cells, fibroblast-like cells proliferate and migrate to the injury site. This action is followed by the formation of new collagen that is arranged in contact with the superficial necrotic zone ${ }^{31}$. 
The results of this present study showed that the application of all material test on inflamed rats dental pulp tissue increased collagen type I density along with the increase of the observation time period. However, ethanolic extract of propolis, flavonoid propolis, and $\mathrm{Ca}(\mathrm{OH})_{2}$, have better effect than non-flavonoid propolis in stimulated collagen type I on inflamed rats dental pulp tissue. Therefore, the present results suggest that both extract ethanolic of propolis and flavonoid propolis increase collagen type I density when used for direct pulp capping, presenting a comparable effect to $\mathrm{Ca}(\mathrm{OH})_{2}$.

\section{Acknowledgements}

The authors would like to thanks to Prof. S Pramono, Ph.D (Faculty of Pharmacy, Gadjah Mada University, Yogyakarta, Indonesia) for his technical assistance in propolis preparation. The authors state that they have no conflicts of interest.

\section{References}

1. Kuropatnicki AK, Szliszka E, Krol W. Historical aspects of propolis research in modern times. Evid Based Complement Alternat Med. 2013;2013:964149. doi: 10.1155/2013/964149.

2. Bogdanov S. Propolis: composition, health, medicine: a review. Bee Prod Sci. 2017; [cited 2017 Jun 2]. Available from: http://www.bee-hexagon. net/files/file/fileE/Health/PropolisBookReview.pdf.

3. Sforcin JM, Fernandes A Jr, Lopes CA, Bankova V, Funari SR. Seasonal effect on Brazilian propolis antibacterial activity. J Ethnopharmacol. 2000 Nov;73(1-2):243-9.

4. Wang K, Zhang J, Ping S, Ma Q, Chen X, Xuan H, et al. Anti-inflammatory effects of ethanol extracts of Chinese propolis and buds from poplar (Populus x canadensis). J Ethnopharmacol. 2014 Aug 8;155(1):300-11. doi: 10.1016/j.jep.2014.05.037.

5. Sforcin JM. Propolis and the immune system: a review. J Ethnopharmacol. 2007 Aug 15;113(1):1-14.

6. Toreti VC, Sato HH, Pastore GM, Park YK. Recent progress of propolis for its biological and chemical compositions and its botanical origin. Evid Based Complement Alternat Med. 2013; 2013: 697390. doi:10.1155/2013/697390.

7. Huang S, Zhang CP, Wang K, Li GQ, Hu FL. Recent advances in the chemical composition of propolis. Molecules. 2014 Nov;19(12):19610-32. doi: $10.3390 /$ molecules 191219610.

8. Anauate Netto C, Marcucci MC, Paulino N, Anido-Anido A, Amore R, de Mendonça S, et al. Effects of typified propolis on mutans streptococci and lactobacilli: a randomized clinical trial. Braz Dent Sci. 2013 Apr;16(2):316.

9. PurraAR, Mushtaq M, Acharya SR, Saraswati V. A comparative evaluation of propolis and $5.0 \%$ potassium nitrate as a dentine desensitizer: A clinical study. J Indian Soc Periodontol. 2014 Jul;18(4):466-71. doi:10.4103/0972-124X.138695.

10. Bhardwaj A, Velmurugan $N$, Sumitha, Ballal S. Efficacy of passive ultrasonic irrigation with natural irrigants (Morinda citrifolia juice, Aloe Vera and Propolis) in comparison with $1 \%$ sodium hypochlorite for removal of E. faecalis biofilm: An in vitro study. Indian J Dent Res. 2013 Jan-Feb;24(1):35-41.

11. Prabhakar AR, Karuna YM, Yavagal C, Deepak BM. Cavity disinfection in minimally invasive dentistry-comparative evaluation of Aloe vera and propolis: A randomized clinical trial. Contemp Clin Dent. 2015 Mar;6(Suppl 1):S24-31. doi:10.4103/0976-237X.152933.

12. Bazvand L, Aminozarbian MG, Farhad A, Noormohammadi $H$,
Hasheminia SM, Mobasherizadeh S. Antibacterial effect of triantibiotic mixture, chlorhexidine gel, and two natural materials Propolis and Aloe vera against Enterococcus faecalis: An ex vivo study. Dent Res J (Isfahan). 2014 Jul;11(4):469-74

13. Parolia A, Kundabala M, Rao NN, Acharya SR, Agrawal P, Mohan M, et al. A comparative histological analysis of human pulp following direct pulp capping with Propolis, Mineral Trioxide Aggregate and Dycal. Aust Dent J. 2010 Mar;55(1):59-64. doi:10.1111/j.1834-7819.2009.01179.x

14. Mejàre IA, Axelsson S, Davidson T, Frisk F, Hakeberg M, Kvist T, et al. Diagnosis of the condition of the dental pulp: a systemic review. Int Endod J. 2012 Jul;45(7):597-613. doi: 10.1111/j.1365-2591.2012.02016.x.

15. Brett $D$. A review of Collagen and Collagen-based Wound Dressing. Wounds. 2008 Dec;20(12):347-56.

16. Rangaraj A, Harding $K$, Leaper $D$. Role of collagen in wound management. Wounds. 2011 Jun;23:347-56.

17. Al-Shaher A, Wallace J, Agarwal S, Bretz W, Baugh D. Effect of propolis on human fibroblasts from the pulp and periodontal ligament. J Endod. 2004 May;30(5):359-61.doi: 10.1097/00004770-200504000-00012.

18. Jahromi MZ, Ranjbarian P, Shiravi S. Cytotoxicity evaluation of Iranian propolis and calcium hydroxide on dental pulp fibroblasts. J Dent Res Dent Clin Dent Prospects. 2014 Summer;8(3):130-3. doi: 10.5681/ joddd.2014.024.

19. Sabir A, Mooduto L, Kaelan C, Horax S. Determination of flavonoid classes in Trigona sp propolis from Luwu Regency, South Sulawesi Province, Indonesia. In: Local Scientific Committee of 44th APIMONDIA International Apicultural Congress, editors. Scientific Program Abstracts of 44th APIMONDIA International Apicultural Congress. Daejeon: Published by Local Scientific Committee; 2015. p.457.

20. Velnar T, Bailey T, Smrkolj V. The wound healing process: an overview of the cellular and molecular mechanisms. J Int Med Res. 2009 SepOct;37(5):1528-42.

21. Ramos AFN, Miranda JL. Propolis: a review of its anti-inflammatory and healing actions. J Venom Anim Toxins incl Trop Dis. 2007;13(4):697-710. doi: 10.1590/S1678-91992007000400002

22. Abdel-Wahed RE, El-Kammar MH, Korittum AS, Edrees IR. Surgical and histological evaluation of the effectiveness of propolis on wound healing. Alexandria J Vet Sci. 2013;39(1):52-63.

23. Bretz WA, Chiego DJ Jr, Marcucci MC, Cunha I, Custódio, Schneider LG. Preliminary report on the effects of propolis on wound healing in the dental pulp. Z Naturfosch C. 1998 Nov-Dec;53(11-12):1045-8.

24. Jain S, Rai R, Sharma V, Batra M. Propolis in Oral Health: A Natural Remedy. World J Pharm Sci. 2014 Jan;2(1):90-4.

25. Kandhare AD, Ghosh P, Bodhankar SL. Naringin, a flavanone glycoside, promotes angiogenesis and inhibits endothelial apoptosis through modulation of inflammatory and growth factor expression in diabetic foot ulcer in rats. Chem Biol Interact. 2014 Aug 5;219:101-12. doi: 10.1016/j. cbi.2014.05.012.

26. Havsteen $\mathrm{BH}$. The biochemistry and medical significance of flavonoids. Pharmacol Ther. 2002 Nov-Dec;96(2-3):67-202.

27. Di Carlo G, Mascolo N, Izzo AA, Capasso F. Flavonoids: old and new aspects of a class of natural therapeutic drugs. Life Sci. 1999;65(4):33753.

28. Sabir A, Tabbu CR, Agustiono P, Sosroseno W. Histological analysis of rat dental pulp tissue capped with propolis. J Oral Sci. 2005 Sep;47(3):135-8.

29. Sabir A. [Antibacterial activity of flavonoid and non-flavonoid of propolis Trigona sp. toward the growth of Streptococcus mutans (in vitro)]. Jitekgi (Sci and Tech Dent J). 2010;7(1):37-42. Indonesian.

30. Nelson Filho P, Silva LA, Leonardo MR, Utrilla LS, Figueiredo F. Connective tissue responses to calcium hydroxide-based root canal medicaments. Int Endod J. 1999 Aug;32(4):303-11.

31. Vesna D, Elena K, Vesna L. Histological evaluation of odontoblast-like cells response after capping application of calcium hydroxide and hydroxilapatite in dog's pulp. Acta Vet. 2007 Jan;57(5-6):573-84. 